\title{
Um novo ciclo, uma nova equipa, o mesmo projecto, a Medicina Geral e Familiar
}

\author{
ANTÓNIO FARIA VAZ*
}

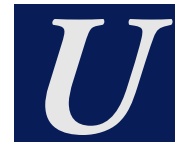

$m$ ciclo termina e outro se inicia, tal como a vida, tal como a natureza, um trajecto e um projecto comum, a Revista.

O ciclo de três anos que agora finda, reflectiu uma liderança e uma equipa com a capacidade para construir futuro, demonstrando que a Medicina Geral e Familiar Portuguesa consegue, quando alia a vontade e o saber à perseverança e à esperança, transformar sonhos em realidade e acreditar que é sempre possivel fazer mais e melhor.

O Dr Jaime Correia de Sousa e a equipa editorial anterior conseguiram que a revista atingisse um elevado nivel, o que é certamente motivo de orgulho para a Medicina Geral e Familiar Portuguesa. ${ }^{1}$ Saudamos o seu magnífico trabalho.

Ao constituir a equipa editorial que agora inicia funções, procurámos garantir uma composição que nos permitisse assegurar qualidade, criatividade, irreverência, e originalidade. Ao aliarmos o saber e a experiência de colegas que são referências incontornáveis da Medicina Geral e Familiar Portuguesa, à qualidade. conhecimento e excelência clínica de uma nova geração de Médicos de Família, pensamos ter reunido as condições para levarmos a bom porto os objectivos a que nos propomos.

De entre os objectivos prioritários que estabelecemos para este triénio e que constituirão o nosso compromisso de mandato, salientamos os seguintes :

- Contribuir para que a Revista Portuguesa de Clínica Geral seja um reflexo vivo e actual da informação, do conhecimento e do saber que diariamente são gerados no seio da nossa especialidade. Para a concretização deste objectivo adoptaremos estratégias activas que nos permitam incentivar a publicação de artigos e de trabalhos de investigação que sejam objecto de comunicação em Congressos e Encontros Nacionais e Internacionais.

- Considerar como estratégica a indexação medline, cuja proposta foi formalmente submetida à National Library of Medicine em Outubro de 2007. rece merecerem tratamento específico e aprofundado, como sejam a relação e comunicação médico doente, a família, a ética, a sociologia e a história. Não menos importante, perspectivamos vir a incluir uma secção dedicada a eventos e manifestações culturais. Para cada uma destas secções especializadas, procuraremos identificar personalidades relevantes e médicos de familia que tenham motivação e disponibilidade para os desenvolverem.

- Procurar promover a colaboração e a cooperação com os departamentos Universitários de Medicina Geral e Familiar de cada Faculdade e com as Coordenações do Internato Complementar.

- Desenvolver actividades de promoção da Revista, incentivando a sua leitura e cativando mais colegas para a entrega de artigos. A concepção deste número da revista, deve-se ainda, quase na totalidade, à equipa editorial anterior, que trabalhou intensamente para que a transição de equipas editoriais se efectuasse com o mínimo de sobressaltos. O seu empenho e dedicação marcaram-nos profundamente, constituindo mais uma prova de eficácia, capacidade de trabalho e espirito solidário. Merecedores da nossa mais elevada estima e gratidão.

Este número da revista tem uma particularidade que gostaria de realçar: a significativa participação da Academia Portuguesa de Medicina Geral e Familiar.

O Prof. Luis Rebelo, da Faculdade de Medicina de Lisboa relata-nos a sua experiência na Consulta de cessação tabágica do Centro de Saúde de Alvalade.

O Dr. José Augusto Simões, docente da Universidade de Aveiro, apresenta-nos o dossier que coordenou, subordinado ao tema Ética, presenteando-nos com um excelente editorial, onde contextualiza a importância dos valores éticos na consulta de Medicina Geral e Familiar. De realçar, a sua afirmação de que $21 \%$ das consultas envolvem problemas éticos, pelo que o conhecimento da ética estimula a reflexão e melhora a capacidade para tomar decisões. A ética não é um manual de comportamento, mas um saber necessário e conveniente. 
O Prof. Alberto Pinto Hespanhol e a Prof. ${ }^{a}$ Luciana Couto, da Faculdade de Medicina da Universidade do Porto, em colaboração com o Dr. Carlos Martins do Centro de Saúde de São João do Porto, apresentam-nos um artigo em que abordam alguns aspectos relacionados com a perspectiva ética e relacional na consulta de Medicina Geral e Familiar, bem como os aspectos conceptuais da prevenção e da promoção da saúde, da educação para a saúde e dos modelos de consulta.

A Prof. ${ }^{a}$ Isabel Santos, da Faculdade de Ciências Médicas da Universidade Nova de Lisboa, também no contexto do dossier de ética, refere-se aos pedidos desapropriados de certificados, esclarecendo os critérios para a sua designação, os princípios e as obrigações essenciais do médico e as estratégias ajustadas à sua resolução.

Ainda integrando o dossier de ética, a colega Mónica Granja realça a problemática das consultas realizadas na presença de terceiros e dos desafios que colocam.

Os Drs. Rosalvo de Almeida e Raquel Braga, pronunciam-se sobre a ética da referenciação médica, dos valores éticos que a ela devem presidir e propõem-nos um modelo para as boas práticas de referenciação .

Por último, fechando este importante dossier, o Dr. António Lourenço, médico de família e director de serviços da Sub-Região de Saúde de Santarém, elabora um conjunto de notas e reflexões sobre terapêuticas e exames complementares a pedido dos doentes, discorrendo sobre o significado desses pedidos no contexto da relação médico doente.

Também muito significativa neste número, é a elevada participação de colegas do internato complementar de Medicina Geral e Familiar.

Da Unidade de Saúde Familiar Horizonte, as Dr. ${ }^{\text {as }}$ Mariana Tudela e Filipa Almeida Lobo apresentam-nos um caso de polipatologia que ilustra e justifica a necessidade de adoptarmos novos modelos de prestação de cuidados que permitam a gestão integral da doença crónica centrada na pessoa. Realce-se a forma magistral como nos são expostos os instrumentos de avaliação familiar e funcional.

Da extensão do Centro de Saúde do Seixal, a Dr. ${ }^{a}$ Vera Santos relata-nos um caso de trombose venosa central que se manifestou primariamente como cefaleia. O interesse do que nos é reportado centra-se no facto das cefaleias constituírem um motivo frequente de consulta em Medicina Geral e Familiar, inúmeras vezes manifestação de doenças prevalentes e auto-limitadas mas, como é salientado, poderem ser também a primeira manifestação de doenças graves e raras, que exigem atenção e cuidados apropriados.

Finalmente, as secções já habituais da revista, os POEMS, que continuam a contar com a colaboração do Dr. Jesus Perez Sanchez e da nova equipa editorial (Dr. Pedro Pacheco e Dr
Rita Viegas) e o Clube de Leitura, que será a partir deste momento coordenado pelos Drs. Daniel Pinto e Marta Fragoeiro.

Publicamos ainda o Îndice de Autores e de Assuntos cujo autoria se deve integralmente ao esforço da $\mathrm{Sr}^{\mathrm{a}} \mathrm{D}$. Adília Silva.

Interessante, iniciarmos este ciclo no preciso momento em que uma nova ministra toma posse, em que um "think-thank" de Cuidados Primários da Saúde, promovido pela Escola Nacional de Saúde, tem lugar e se desenvolve, em que são publicados instrumentos legais que pretendem consubstanciar a reforma dos cuidados primários.

Vivem-se sentimentos que combinam a vontade e o desejo de mudar, a vontade de fazer melhor por parte de quem aderiu à reforma e nela aposta e acredita. Nunca na história da Medicina Geral assistimos a uma alteração tão profunda na organização e no funcionamento dos Centros de Saúde. Nunca estivemos tão perto de nos apropriarmos do nosso futuro. As Unidades de Saúde Familiar são sementes de futuro, e pela dimensão e qualidade dos profissionais de saúde que as constituem a reforma certamente acontecerá.

Temos consciência que estamos perante uma reforma que não procurou definir estratégias de implementação que permitissem a sua aplicação universal, ao optar por um modelo centrado na capacidade de auto-organização dos profissionais de saúde, dificilmente seria possivel a sua aplicação generalizada; atendendo às especificidades de cada Centro de Saúde, às particularidades, expectativas, interesses e vontade de cada um dos profissionais de saúde, a que se deve associar a enorme carência de profissionais e a enorme contenção e restrição orçamental.

No entanto, se a reforma e a implementação das Unidades de Saúde Familiares constituem razão e motivo para renovarmos a nossa esperança no futuro, a sua consolidação obriga e implica que se centre agora a atenção no envolvimento de todos os profissionais de saúde. A Medicina Geral e Familiar é o sustento e base do nosso sistema de saúde, o garante da continuidade de cuidados e da equidade de acesso aos serviços de saúde.

É imprescindivel que as decisões políticas cumpram os valores éticos que devem presidir à prestação de cuidados de saúde, sendo neste caso essencial garantir o cumprimento dos valores relativos à justiça e à beneficência.

Está portanto a Medicina Geral e Familiar perante um enorme desafio,

\section{REFERÊNCIAS BIBLIOGRÁFICAS}

1. Sousa JC. A idade adulta a Revista Portuguesa de Clínica Geral no último triénio.Rev Port Clin Geral 2007; Nov-Dez 23 (6):659-663. 